Hydrology and Earth System Sciences, 6(2), 255-265 (2002) C EGS

\title{
Assessing the effects of land-use changes on annual average gross erosion
}

\author{
Armando Brath, Attilio Castellarin and Alberto Montanari
}

Università di Bologna, Viale Risorgimento, 2 - 40136 Bologna, Italy

Email for corresponding author: attilio.castellarin@mail.ing.unibo.it

\begin{abstract}
The effects of land-use changes on potential annual gross erosion in the uplands of the Emilia-Romagna administrative region, a broad geographical area of some $22000 \mathrm{~km}^{2}$ in northern-central Italy, have been analysed by application of the Universal Soil Loss Equation (USLE). The presence of an extended mountain chain, particularly subject to soil erosion, makes the estimation of annual gross erosion relevant in defining regional soil-conservation strategies. The USLE, derived empirically for plots, is usually applied at the basin scale. In the present study, the method is implemented in a distributed framework for the hilly and mountainous portion of Emilia-Romagna through a discretisation of the region into elementary square cells. The annual gross erosion is evaluated by combining morphological, pedological and climatic information. The stream network and the tributary area drained by each elementary cell, which are needed for the local application of the USLE, are derived automatically from a Digital Elevation Model (DEM) of grid size $250 \times 250 \mathrm{~m}$. The rainfall erosivity factor is evaluated from local estimates of rainfall of six-hour storm duration and two-year return period. The soil erodibility and slope lengthsteepness factors are derived from digital maps of land use, pedology and geomorphology. Furthermore, historical land-use maps of the district of Bologna (a large portion - $3720 \mathrm{~km}^{2}$ - of the area under study), allow the effect of actual land use changes on the soil erosion process to be assessed. The analysis shows the influence of land-use changes on annual gross erosion as well as the increasing vulnerability of upland areas to soil erosion processes during recent decades.
\end{abstract}

Keywords: USLE, gross erosion, distributed modelling, land use changes, northern-central Italy

\section{Introduction}

The Universal Soil Loss Equation (USLE), (Wischmeier and Smith, 1965; 1978) is probably the best-known empirical formula for predicting long-term (annual, monthly) gross erosion and is used frequently by soil conservationists around the world. The original equation, derived by analysis of extensive field measurements over small agricultural plots, was suitable only for spatial scales up to 1 ha $(0.01$ $\mathrm{km}^{2}$ ) and time scales of a month or year, and so was immediately applicable to only a limited number of practical problems. However, many researchers have extended the approach to different spatial and time scales. Julien and Frenette (1987) introduced a correction factor to extend the applicability of USLE to larger areas and large catchments. Young et al. (1987) used an event-based extension of the USLE for medium to large catchments within the Agricultural Non-Point Source Pollution (AGNPS) model; a catchment is divided into elementary cells, regarded as separate hydrological units and the USLE is applied to each elementary cell to predict soil erosion. More recently, Kinnel (2000) proposed including in AGNPS a modified USLE (USLE-M), which is more suited to event-based prediction and accounts for the impact of upslope runoff on soil erosion. Jain and Kothyari (2000) presented a catchment scale and event-based application of the USLE using a Geographical Information System (GIS) to identify sediment source areas and predict storm sediment yield; the performance was assessed by comparing observed and simulated storm sediment yields for two Indian catchments. To investigate the influence of spatial resolution on soil loss prediction, Molnár and Julien (1998) compared USLE calculations on different spatial scales of discretisation of the basin area into elementary grid cells, of sizes ranging from $30 \times 30 \mathrm{~m}$ up to $6 \times 6 \mathrm{~km}$. Pilotti and Bacchi (1997) applied the 
distributed form of the USLE to an alpine catchment in Italy.

The present study makes a regional GIS application of the USLE by implementing the algorithm proposed by Pilotti and Bacchi (1997) to the $22000 \mathrm{~km}^{2}$ hilly and mountainous portion of the Italian administrative region Emilia-Romagna.

The study focuses on two main aspects. The first assesses whether a regional scale application can provide useful indications about natural vulnerability to soil erosion of wide mountainous areas. Such estimates at the regional scale may assist in defining regional soil conservation strategies and can identify the most vulnerable areas where smaller scale evaluations of the erosion risk should be made. The second main aspect highlights, again on a regional scale, the effects on broad geographical areas of land-use changes on erosion vulnerability. Land-use maps for 1955 and 1980, available for a sub-portion of the present study area, show the extent of the changes in land usage in the hilly and mountainous areas over the period. This evidence suggests a fresh application of the approach on the basis of different historical land use scenarios.

\section{Estimation of upland erosion}

An extensive study by Wischmeier and Smith (1965) led to the definition of the USLE. This empirical relation computes the long-term (usually monthly or yearly) soil loss at a given location as follows:

$$
A=R K\left[(\lambda / 22.13)^{m}\right] S C P
$$

where $A$ is the soil loss in tons per unit area and time $[\mathrm{t} /(\mathrm{ha} \cdot \mathrm{y})] ; R$ is the rainfall erosivity factor $[(\mathrm{MJ} \cdot \mathrm{mm}) /$ $(\mathrm{ha} \cdot \mathrm{h} \cdot \mathrm{y})] ; K$ is the soil erodibility factor $[(\mathrm{t} \cdot \mathrm{h}) /(\mathrm{MJ} \cdot \mathrm{mm})] ; \lambda$ is the field length $(\mathrm{m})$ normalised to a plot length of 22.13 $\mathrm{m} ; m$ is an exponent depending on field slope (dimensionless); $S$ is the field slope factor normalised to a field slope of $9 \%$ (dimensionless), $C$ is the cropping management factor normalised to a tilled area with continuous fallow (dimensionless) and $P$ is the conservation practice factor normalised to straight-row farming up and down the slope (dimensionless).

Equation (1) is suitable for plots with homogeneous characteristics and, therefore, it is not directly applicable when the climatic, morphological, soil-type and soil-use characteristics vary along the slope. In the study by USDAARS (1991), the USLE is extended to heterogeneous plots by subdividing them along the slope into segments, whose within-segment physiographic, climatic and soil characteristics can be assumed constant. The approach then evaluates the total soil loss per unit-width, $A\left(x_{i}\right)$, by the equation:

$$
\begin{aligned}
A\left(x_{i}\right) & =\sum_{j=1}^{i} \Delta A_{j}= \\
& \sum_{j=1}^{i} \frac{1}{22.13^{m_{j}}} R_{j} K_{j}\left[x_{j}^{m_{j}+1}-x_{j-1}^{m_{j}+1}\right] S_{j} C_{j} P_{j}
\end{aligned}
$$

where $x_{j}$ and $x_{j-1}(\mathrm{~m})$ are the distances from the top of the plot to the lower and upper edges of the $j$-segment respectively, and $\Delta A_{j}$ is the segment contribution to $A\left(x_{i}\right)[(\mathrm{t} \cdot \mathrm{m}) /(\mathrm{ha} \cdot \mathrm{y})]$.

Starting from Eqn.(2), Pilotti and Bacchi (1997) developed an algorithm for the distributed application of the USLE to catchments of any dimension. Firstly, the flow paths are identified within the drainage basin on the basis of a Digital Elevation Model (DEM). Secondly, the overland grid cells are distinguished from those of the river network by choosing a constant Critical Source Area (CSA), (Montgomery and Foufoula-Georgiou, 1993), so that a given grid cell belongs to the river network if its contributing area (i.e. the area that the cell drains) is greater than the CSA. Then, the procedure regards each flow path as a single hillslope subdivided into separate elementary cells where the specific soil-loss $\overline{\Delta A}[\mathrm{t} /(\mathrm{ha} \cdot \mathrm{y})]$ is evaluated. The $j$-cell $\overline{\Delta A_{j}}$ can be evaluated as follows:

$$
\overline{\Delta A_{j}}=\left(\frac{g}{22.13}\right)^{m_{j}} R_{j} K_{j}\left[n_{j}^{m_{j}+1}-n_{j-1}^{m_{j}+1}\right] S_{j} C_{j} P_{j}
$$

where $g(\mathrm{~m})$ is the DEM grid-size, and $n_{j}$ (dimensionless) is the number of cells that the $j$-cell drains. Equation (3) is derived from (2) on the assumption that the $\Delta A_{j}$ due to the sheet erosion of two (or more) convergent flow paths is produced by the same two (or more) flow paths in series (Pilotti and Bacchi, 1997).

\section{Regional scale upland erosion: an Italian case study}

The methodology outlined above is applied within a GIS environment to an Italian regional case study (Fig. 1), the Emilia-Romagna administrative region $\left(22000 \mathrm{~km}^{2}\right)$, for which data on morphological, climatic and soil-use characteristics are available. The approach was applied, in particular, to the hilly and mountainous portion (altitude $\geq$ $60 \mathrm{~m}$ a.s.1.) of the region, thus excluding from the study the flat areas which are naturally less exposed to sheet and rill erosion processes.

The flow paths are retrieved automatically for the study area from a DEM of grid size $250 \times 250 \mathrm{~m}$, after removing the pits and flat areas, using an eight-direction pour point algorithm (ESRI, 1994). This algorithm defines the flow direction for a given grid cell as the direction of steepest descent among the eight possible choices connecting the 
cell to the eight surrounding grid cells. Then, the upslope contributing area for each cell is calculated by summing the areas of all upslope cells draining into it. A contributing area of 12.5 ha ( 2 grid cells) was chosen as the CSA and used to differentiate overland cells to which to apply (3), from stream-network cells for which (3) is no longer appropriate.

Although the accuracy and reliability of computations would improve markedly at higher resolutions, a $250 \mathrm{~m}$ gridsize was deemed adequate for a distributed application of the USLE to identify the spatial variability of vulnerability to soil erosion for the whole region of study.

The annual average rainfall erosivity factor $R_{j}[(\mathrm{MJ} \cdot \mathrm{mm}) /$ $(\mathrm{ha} \cdot \mathrm{h} \cdot \mathrm{y})]$ was evaluated for any given cell $j$ as a function of the local rainfall depth for a storm duration of six hours and a return period of two years, $D_{6 h r: 2 y, j}$, by the empirical equation (Wischmeier and Smith, 1978):

$$
R_{j}=0.417 D_{6 h r, 2 y, j}{ }^{2.17}
$$

Although Eqn. (4) was derived originally for northwestern USA, its estimates of the annual rainfall erosivity factor correspond to the values of annual $R$ characteristic of hilly and mountainous areas of the northern Apennine (RERERSO, 1990; Bianchi et al. 2001).

The value of $D_{6 h r, 2 y, j}$ for each cell in the study area was estimated by using the outcomes of a recent regional frequency analysis of rainfall extremes (Brath and Castellarin, 2001). The study area includes the EmiliaRomagna and Marche regions and extends to $37200 \mathrm{~km}^{2}$. The area is characterised by a rainfall-gauging network with 419 daily and 132 hourly raingauges with record lengths of more than 30 years. The regional analysis provides reliable estimates of the rainfall depth for any return period and storm duration ranging from 1 to 24 hours (Brath and Castellarin, 2001).

A digital soil map, available for the study area, describes soils in terms of their organic matter content and characteristics of texture, relative permeability and average slope (RER Cartographic Service, 1994). The erodibility factor of the soil, $K_{j}[(\mathrm{t} \cdot \mathrm{h}) /(\mathrm{MJ} \cdot \mathrm{mm})]$, was retrieved for the $j$-cell from the digital soil map either by using the abacus proposed by the USLE authors or, where soils have a silt content lower than $70 \%$, by applying the following semiempirical algorithm (Wischmeier et al., 1971):

$$
\begin{aligned}
100 K_{j}=0.129\left[2.1 M_{j}^{1.14}\left(10^{-4}\right)\left(12-a_{j}\right)\right. \\
\left.+3.25\left(b_{j}-2\right)+2.5\left(c_{j}-3\right)\right]
\end{aligned}
$$

with $M_{j}$ (dimensionless) expressed as follows:

$$
M_{j}=\left(\alpha_{j}+\beta_{j}\right)\left(100-\gamma_{j}\right)
$$

where $a_{j}(\%)$ is the soil's content of organic matter, $b_{j}(1$ to 4 ) and $c_{j}$ (1 to 6$)$ are codes depending on the soil's texture and permeability respectively, $\alpha_{j}(\%)$ is the soil's content of silt, $\beta_{j}(\%)$ the content of fine sand and $\gamma_{j}(\%)$ the content of clay. The digital map information concerning soils' average slope was then employed in the evaluation of both $m_{j}$ (see Table 1) and $S_{j}$. $S_{j}$ was estimated by the following equation (Moore and Wilson, 1992):

$$
S_{j}=\left(\sin \theta_{j} / 0.0896\right)^{1.3}
$$

where $\theta_{j}$ is the slope gradient in degrees. Equation (7) was adopted and validated in a recent study for the estimation of soil erosion and sediment yield using GIS (Jain and Kothyari, 2000).

The cropping-management factor $C_{j}$ (dimensionless) was evaluated as a function of the soil-use characteristics of the $j$-cell according to the indications reported in the USLE manual (Wischmeier and Smith, 1965, 1978). These characteristics were derived from the digital land-use map of Emilia-Romagna for the year 1992. This map derives from a photo-interpretation of 1:100 000 satellite images and is produced in accordance with the guidelines defined within the European research programme CORINE (CoORdination of INformation on the Environment, European Environment Agency). Finally, the factor $P_{j}$ (dimensionless) was set to 0.5 for all cells corresponding to plots and arboreal cultivation and, due to the absence of agricultural practices, equal to one everywhere else. The value 0.5 is an average value for farming on contours or contour strip cropping and slopes of 5-15\%, as in this case (see for instance Shen and Julien, 1993).

The map in Fig. 2 shows the annual average gross erosion as computed by applying the approach described above. The map distinguishes areas of very low gross erosion $\left(0-10 \mathrm{tha}^{-1} \mathrm{y}^{-1}\right)$ from those with low $\left(10-50 \mathrm{t} \mathrm{ha}^{-1} \mathrm{y}^{-1}\right)$, moderately high (50-150 tha- $\left.\mathrm{y}^{-1}\right)$ and high erosion (150$500 \mathrm{tha}^{-1} \mathrm{y}^{-1}$ ) (Wischmeier and Smith, 1978). The application shows differences in annual gross erosion from one zone to another and identifies the most vulnerable areas. The intermediate zone between the mountain region (southern

Table 1. Values of the exponent $m$.

\begin{tabular}{ll}
\hline$m$ & slope (\%) \\
\hline 0.2 & $<1 \%$ \\
0.3 & $1-3 \%$ \\
0.4 & $3-5 \%$ \\
05 & $>5 \%$ \\
\hline
\end{tabular}




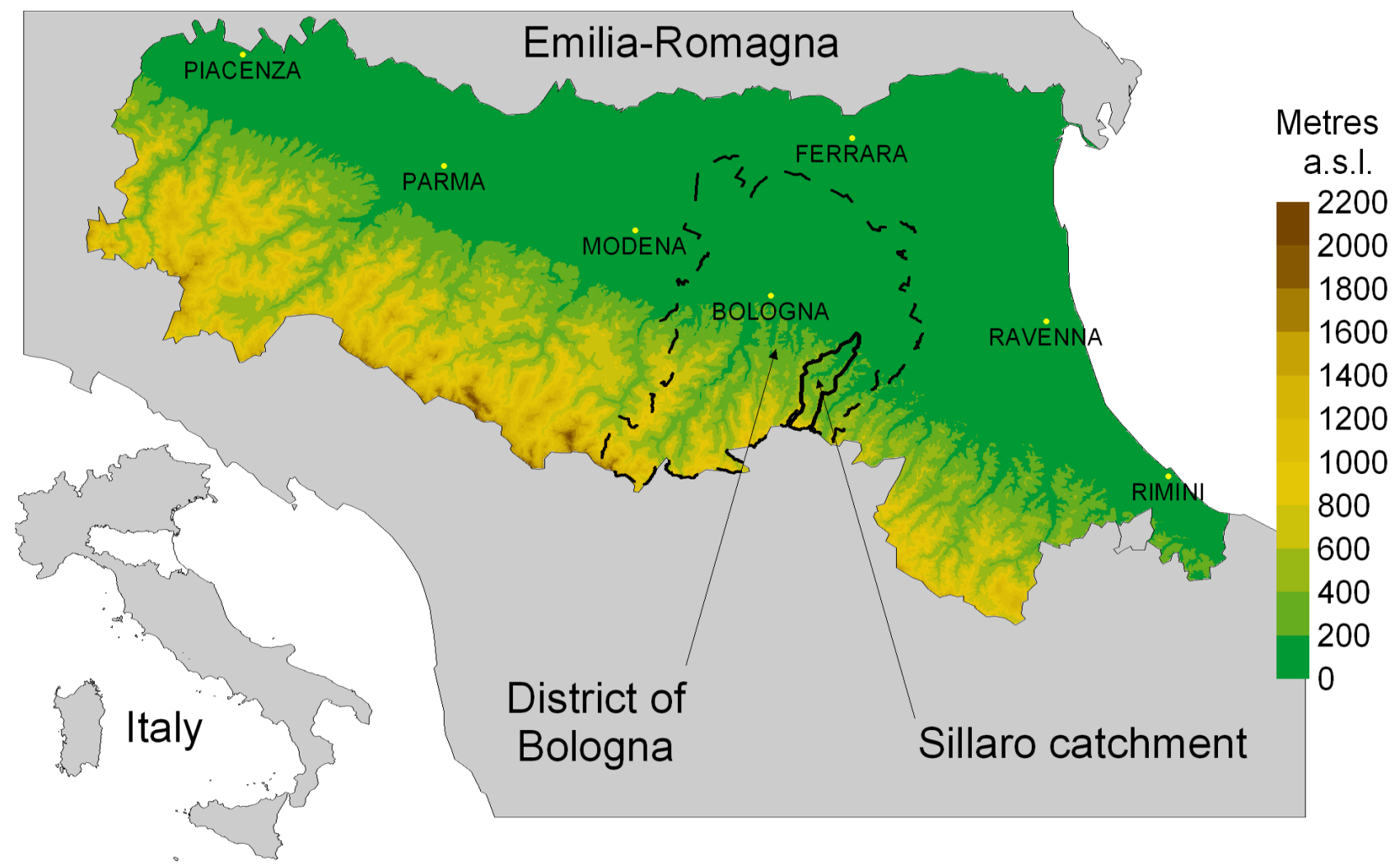

Fig. 1. Emilia-Romagna administrative region, district of Bologna and Sillaro Torrent catchment.

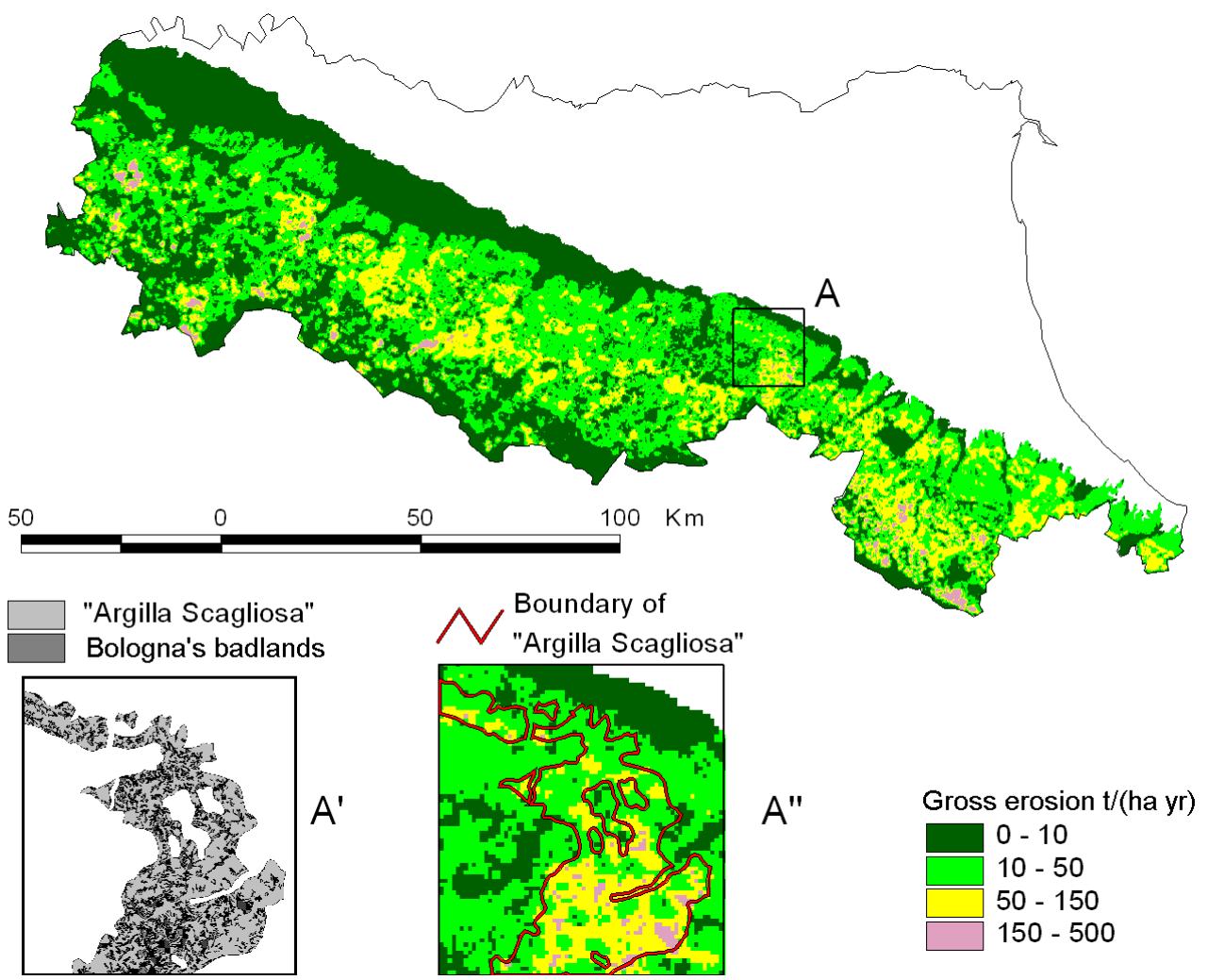

Fig. 2. Emilia-Romagna: estimates of the annual average gross erosion for the hilly and mountainous portion. 
border) and the foothills is the most likely to experience moderately high and high soil losses because of an unfavourable combination between the rainfall erosivity capacity and the erodibility of soils. In this intermediate area, the rainfall erosivity capacity is lower than that in the mountain regions and higher than that in the foothills, while the strength of the soil is much lower in the foothills and higher in the mountain region.

\section{MODEL VALIDATION}

The empirical derivation of the original USLE formulation affects all approaches that were developed from the USLE itself, such as the distributed approach that this analysis adopts. Therefore, the application of any USLE-based approach to a geographical context that differs, for example climatically or geologically, from the area where the USLE originated must be validated against field measurements.

The study by Pilotti and Bacchi (1997) validated the distributed approach by applying it to an Italian alpine catchment located upstream from a dam and comparing the results with measurements of reservoir sedimentation.

The regional estimates of annual average gross erosion in the present case study were assessed qualitatively (i.e. visually) and quantitatively by reference to the district of Bologna (see Fig. 1).

Firstly, the gross erosion patterns identified by the model (Fig. 2) are compared visually with the observed soil vulnerability to sheet and rill erosion. For example, window A, in Fig. 2, encircles a hilly zone south of Bologna characterised by areas with sharp erosional sculptures, lacking or with scanty vegetation and normally dry watercourses (i.e. Bologna's badlands). These areas are associated with "Argilla Scagliosa" outcrops (i.e. chaotic assemblage with an argillitic matrix affected by slaty cleavage, see Pini, 1999), and are extremely vulnerable to sheet and rill erosion.

Figure 2-A' shows for window A the "Argilla Scagliosa" outcrops in grey and some of Bologna's badlands in dark grey, whereas Fig. 2-A" compares the estimated annual gross erosion with the boundaries of the "Argilla Scagliosa" outcrops. Figs. 2-A' and 2-A" show a notable agreement between Bologna's badlands and the simulated patterns of moderately high (50-150 tha $\left.\mathrm{ha}^{-1} \mathrm{y}^{-1}\right)$ and high (150-500 $t \mathrm{tha}^{-1} \mathrm{y}^{-1}$ ) erosion risk. This example confirms on a visual basis the validity of the pattern identified by the model.

Secondly, a quantitative validation is performed. To assess the accuracy of the model estimates, the annual gross erosion estimated for the Sillaro Torrent catchment $\left(138 \mathrm{~km}^{2}\right)$ in the district of Bologna (Fig.1) was compared with measurements of suspended sediment load. An extensive measurement
Table 2. Measures of the suspended sediment load for the Sillaro catchment (Pavanelli et al., 2001).

\begin{tabular}{lccc}
\hline Year & Samples (-) & $\begin{array}{l}\text { Suspended } \\
\text { sed.load (t) }\end{array}$ & $\begin{array}{l}\text { Average sed. } \\
\text { yield (t/ha) }\end{array}$ \\
\hline 1997 Apr.-Dec. & 105 & 81563 & 5.93 \\
1998 Jan.-Dec. & 119 & 59037 & 4.29 \\
1999 Jan.-Dec. & 249 & 159724 & 11.61 \\
Total & 473 & 300324 & 7.94 \\
\hline
\end{tabular}

campaign (473 samples over 33 months between 1997 and 1999) (Table 2) resulted in a total suspended sediment load of 300324 tons (Pavanelli et al., 2001), corresponding to an average annual soil loss of $7.9 \mathrm{tha}^{-1} \mathrm{y}^{-1}$.

The estimate of the average annual gross erosion for the Sillaro Torrent catchment based on the 1992 land-use characteristics is equal to $48.0 \mathrm{tha}^{-1} \mathrm{y}^{-1}$. An estimate of the Sediment Delivery Ratio (SDR: the ratio of annual sediment yield to annual gross erosion) for this catchment can be calculated by using the empirical formula (Shen and Julien, 1993):

$$
\mathrm{SDR}=0.41 A^{-0.3}
$$

where $A$ is the catchment area $\left(\mathrm{km}^{2}\right)$. Equation (8) produces a SDR equal to 0.094 for the Sillaro catchment which, for the 1992 land-use scenario, gives an estimated annual sediment yield of $4.5 \mathrm{tha}^{-1} \mathrm{y}^{-1}$. Shen and Julien (1993) report the empirical relation between SDR and $A$ of Eqn. (8) on a log-log diagram, together with the upper and lower bounds of the range of the experimental data used in its determination; the upper bound suggests a value of SDR of around 0.2 for an area $A$ of $138 \mathrm{~km}^{2}$. The measured annual suspended sediment load of. $7.9 \mathrm{tha}^{-1}$ can be reproduced from the estimated annual gross erosion by using a SDR of 0.16 , which is a feasible value for the Sillaro catchment. This supports the reliability of the order of magnitude of the model estimates of the annual gross erosion.

\section{Recent soil-use changes in the study area}

Recently, considerable changes in land use have occurred in different ways in the various regions of Italy but a few general patterns can be delineated.

From the early 1950 s, the meadows and pastures, which at that time characterised most of the upland regions, 
decreased as increasing industrialisation and urbanisation led to the abandonment of cattle-farming. Hence, these upland areas were left fallow and unproductive.

These patterns are detectable in a map of the district of Bologna (Fig. 1), which describes the land-use dynamics between the years 1955 and 1980 . The map is one of the products of the special project RAISA (Advanced Researches for the Agricultural System Innovation) supported by the National Research Council of Italy, and describes the land-use characteristics, in 1955 and 1980, over the $3720 \mathrm{~km}^{2}$ wide area at 1:50 000 scale (Bertozzi et $a l ., 1992)$. The change in the soil-use characteristics in the district of Bologna between 1955 and 1980 is shown in Fig. 3 in which, for the sake of generalisation, the original 10 land-use classes adopted by the RAISA project (Bertozzi et al., 1992) were merged into 7 major classes: surface water; fallow and unproductive areas; forestlands and woods; meadows and pastures; crops; arboreal cultivation; urbanised areas. The land-use changes, already evident in the maps of Fig. 3, are summarised in the bar-diagram of Fig. 4. The height of each bar segment is proportional to the relative areal extent of a given land-use type so that the heights of the different sectors sum to $100 \%$. While only slight changes can be observed in Fig. 4 when considering the areal extent of surface water and woods and crops, meadows and pastures fell from $23.7 \%$ in 1955 to $3 \%$ in 1980 . This reduction was balanced by the increase in arboreal cultivation, unproductive areas and, only marginally, by the growth of urbanised areas. Although urbanised areas increased by more than $500 \%$ over the 25 years, their total extent in 1980 was still less than $5 \%$ of the entire district.

\section{Effects of land-use changes on upland erosion}

Such land-use changes can have local, regional or global effects on hydrological processes (Calder, 1993) including the alteration of the natural vulnerability of a given region to soil erosion. To highlight the effects of land-use changes on soil erosion, the procedure presented earlier was applied in turn to the land-use scenarios of 1955 and 1980 for the district of Bologna. It was assumed that the climatic and morphological conditions were the same as those considered in the earlier application to the entire Emilia-Romagna region. While the small time span (25 years) ensures that this assumption is reasonable as regards the morphology of the area being studied, the same cannot be said for the climatic characteristics; Montanari et al. (1996) and Brath et al. (2000) analysed Italian rainfall series and pointed out the possible presence of non-stationarity. Nevertheless, the present paper focuses on the effects of land-use changes on upland erosion independent of any effects induced by climate change.

Prior to evaluating the annual gross erosion for the different land-use scenarios of the district of Bologna it is worth highlighting that the land-use dynamics presented in the previous section refer to the entire district. To get a more objective perception of the effects of land-use changes on gross erosion, the land-use dynamics between 1955 and 1980 were re-analysed referring only to Bologna's uplands. Using the grid environment with resolution $250 \times 250 \mathrm{~m}$ as previously and adopting the criteria used in the evaluation of the annual average gross erosion for Emilia-Romagna (i.e. cell altitude $\geq 60 \mathrm{~m}$ a.s.l.; $\mathrm{CSA}=12.5 \mathrm{ha}$ ), the grid cells belonging to the district of Bologna in which to apply (3) were finally identified. The land-use dynamics for this subset of grid cells are summarised in Fig. 5 using the layout adopted in Fig. 4. The same patterns that were detected with respect to the entire district are still visible when considering only the upland areas, even though in this case a few different features are present. There is still an important reduction in the extent of the meadows and pastures, which shrank from almost $50 \%$ of the upland territory in 1955 to less than $6 \%$ in 1980, whereas urbanised areas, fallow land and arboreal cultivation have expanded. When considering only the upland portion of the district of Bologna, a remarkable increase also characterises the crops, which on average do not show significant changes between 1955 and 1980 throughout the district (Fig. 4).

The evaluation of the annual average gross erosion relative to the 1955 and 1980 land-use scenarios was performed by re-applying the procedure presented earlier, except for the computation of the cropping-management factor $C$ and the conservation practice factor $P$ for the 1955 scenario. The simplified land-use classification adopted for the 1955 and 1980 scenarios ( 7 major land-use classes) required merging and averaging the $C$ values reported in the USLE manual for the different soil-uses. The values adopted in the present study are reported in Table 3 . The $P$ factor for crops and

Table 3. Values of the cropping-management factor $C$.

\begin{tabular}{ll}
\hline Land-use & $C(-)$ \\
\hline Urbanised areas & 0.000 \\
Arboreal cultivation & 0.259 \\
Crops & 0.100 \\
Meadows and pastures & 0.013 \\
Forestlands and woods & 0.005 \\
Fallow and unproductive areas & 0.020 \\
Surface water & 0.000 \\
\hline
\end{tabular}




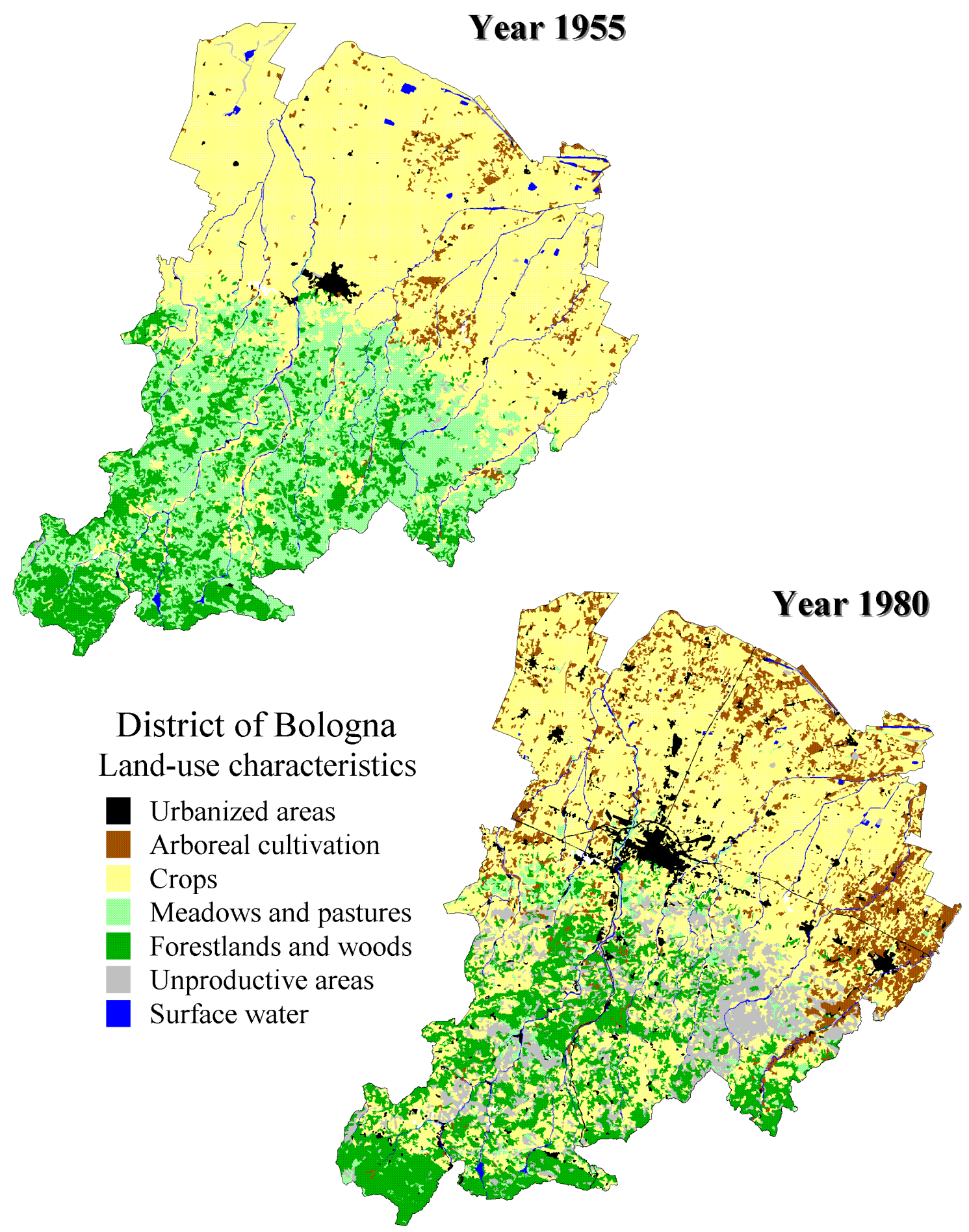

Fig. 3. District of Bologna: land-use maps for 1955 and 1980.

arboreal cultivation in 1955 was set equal to 0.75 instead of 0.5, which was used for the 1992 and 1980 scenarios. This value took into account the fact that, according to Bertozzi et al. (1992), at that time farmers had less awareness of the strong interactions between cropping practices and soil losses, so that soil conservation was practised less than nowadays.

As a result of the computations, Fig. 6 shows the average annual soil loss relative to the 1955 and 1980 scenarios for the hilly and mountainous portion of the district of Bologna. 


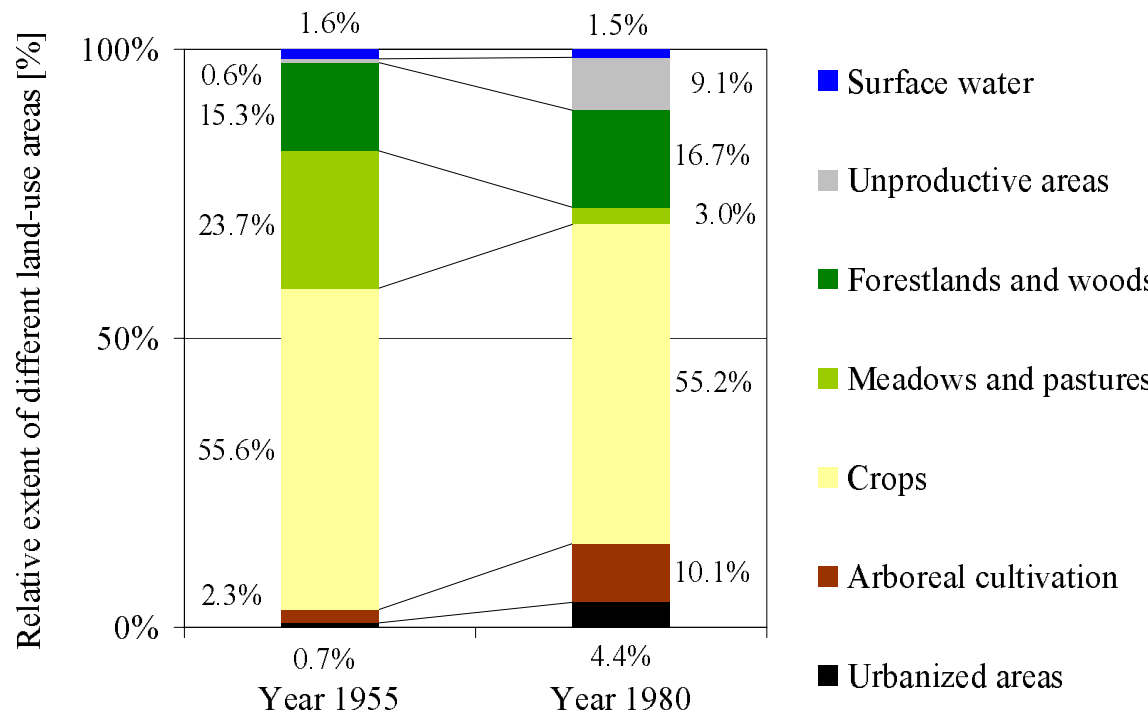

Fig. 4. District of Bologna: land-use dynamics between 1955 and 1980.

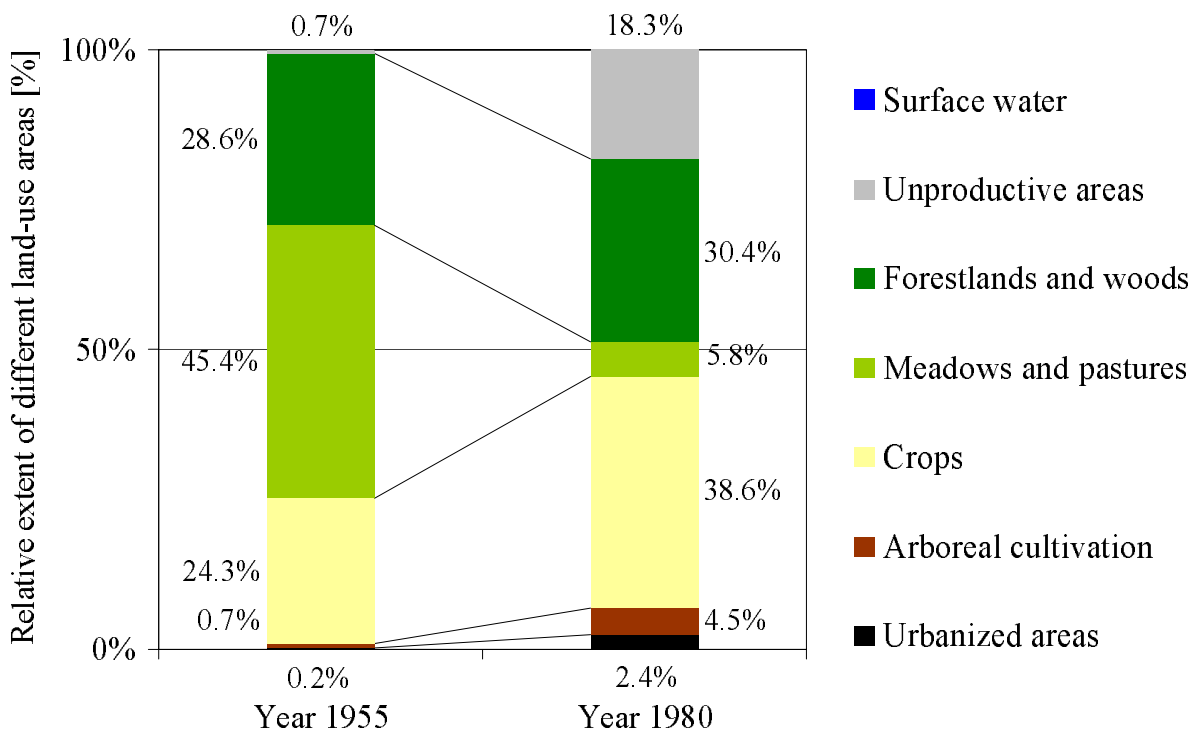

Fig. 5. Uplands of the District of Bologna: land-use dynamics between 1955 and 1980.

The comparison of the maps shows a significant increase in annual gross erosion from 1955 to 1980. In 1955, the majority of the uplands are characterised by sustainable gross erosion $\left(0-10\right.$ tha $\left.^{-1} \mathrm{y}^{-1}\right)$ or, in the worst case, low gross erosion (10-50 tha-1 $\left.\mathrm{y}^{-1}\right)$. In 1980, the areas with low (10-50 tha $\left.{ }^{-1} y^{-1}\right)$ and moderately high $\left(50-150\right.$ tha $\left.^{-1} y^{-1}\right)$ gross erosion are significantly larger than in 1955 . Hence, some of the areas that are rated among the sustainable or low gross erosion classes in 1955 appear to be vulnerable in 1980 (see for instance the central-western portion of Bologna's uplands in Fig. 6).
Figure 7 should clarify the real contribution of each landuse dynamic in the modification of the annual average gross erosion from 1955 to 1980 . The diagram has two bars, one referring to 1955 and the other to 1980; the length of each is proportional to the average annual gross erosion in the corresponding year. Moreover, Fig. 7 shows the contributions of different land-uses to the average value of annual gross erosion by using features similar to those of Figs. 4 and 5. The diagram depicts a significant increment in the average gross erosion over the mountainous portion of the district, which changes from $15.7 \mathrm{tha}^{-1}$ in 1955 to 


\section{Gross erosion [t/(ha y)]}

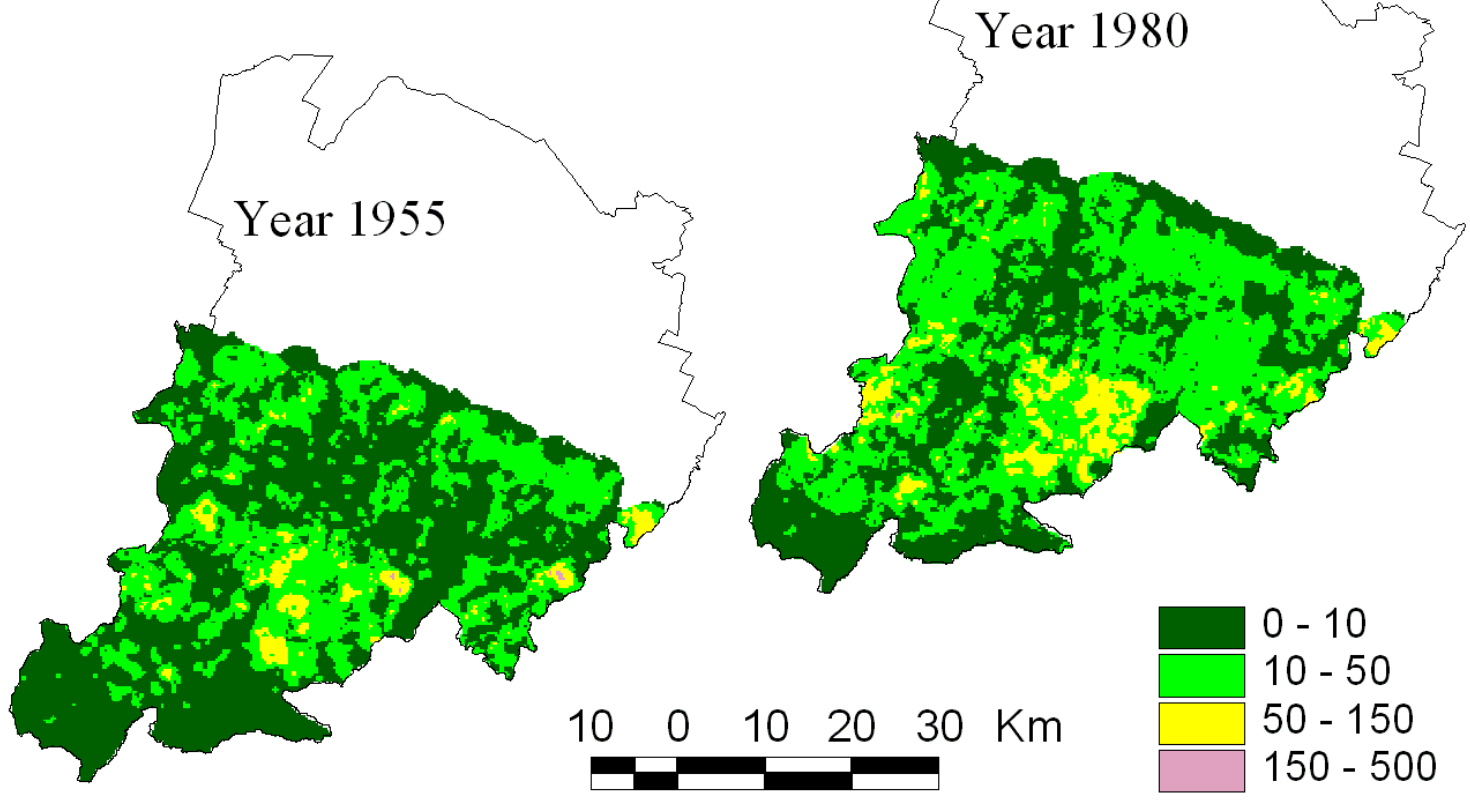

Fig. 6. District of Bologna: Estimates of the annual average gross erosion for the hilly and mountainous areas in two landuse scenarios, 1955 and 1980.

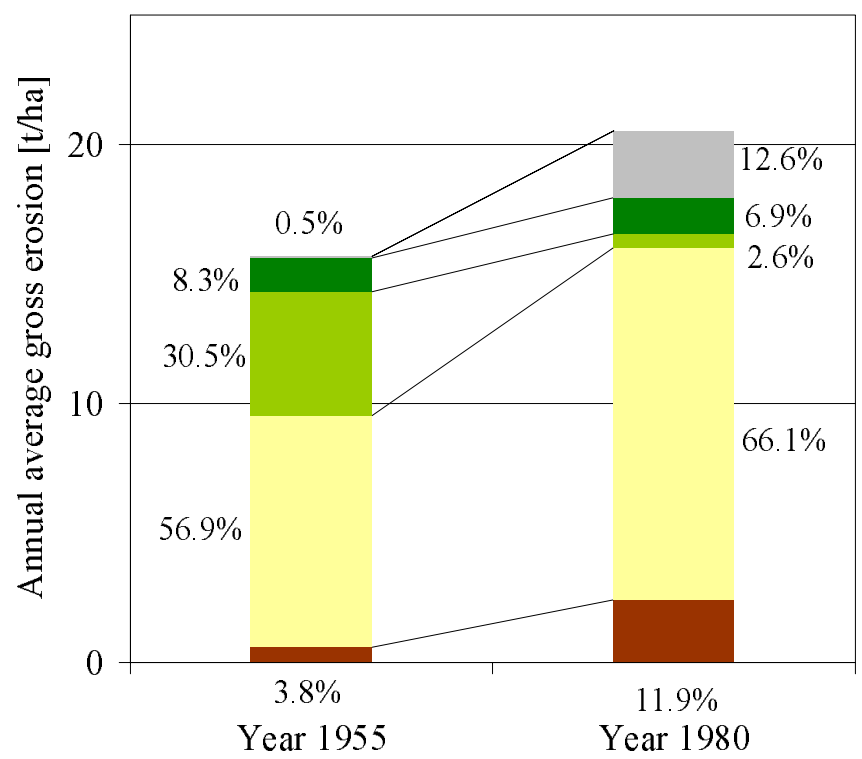

Surface water

Unproductive areas

Forestlands and woods

Meadows and pastures

Crops

Arboreal cultivation

Urbanized areas

Fig. 7. District of Bologna: land-use type contribution to annual average gross erosion in two land-use scenarios, 1955 and 1980.

20.5 tha $^{-1}$ in 1980 , the reasons for this change being visible from the diagram itself. The reduction in the extent of meadows and pastures which mitigate soil loss, is balanced by the gowth of the areas of more vulnerable land-use types, such as fallow land, crops and arboreal cultivation. In particular, crops and arboreal cultivation are vulnerable to soil erosion (see $C$ coefficients on Table 2) due to the seasonal tilling practices and the characteristic reduction in canopy.

According to this analysis, Fig. 7 shows that the 
vulnerability of the study area to soil erosion processes increased significantly over 25 years. The lack of information available on the area of interest did not allow validation of the annual gross erosion estimates obtained from the model implementation to the district of Bologna in the 1955 and 1980 land-use scenarios. Due to the approximations associated with the resolution adopted (i.e. DEM with grid size $250 \times 250 \mathrm{~m}$ ) and the assumption of considering the same $R$ factor for 1955 and 1980, the model outcomes provide estimates of the annual gross erosion in the two historical scenarios that might be affected by significant approximations. Nevertheless, supported by the validation of the model estimates for the 1992 land-use scenario, Figs. 6 and 7 should provide a reliable picture of how the recent land-use changes in the district of Bologna affect the vulnerability of soils to sheet and rill erosion.

\section{Conclusions}

The paper analyses the possible effects of land-use changes on gross erosion by a regional distributed application of the USLE, making use of information on region morphology, climate, geology, pedology and land-use characteristics.

Initially, the methodology was applied to a wide hilly and mountainous area of the Emilia-Romagna region (22 000 $\mathrm{km}^{2}$ ) and validated for a portion of Bologna's uplands. The application highlights remarkable differences in the vulnerability to soil erosion within the study area and allows identification of the most erosion-prone areas; these were located in an intermediate belt between the mountainous portion of the region (southern part of the study area) and the foothills, due to an unfavourable combination of the rainfall erosivity capacity and the erodibility characteristics of soils in this area.

In addition, the approach has been implemented on a smaller area, including the mountainous and hilly portions of the district of Bologna ( $3720 \mathrm{~km}^{2}$ in size), for two different land-use scenarios dated 1955 and 1980. Under the hypotheses adopted in the analysis and for this particular case study, the results show the influence of land-use changes on gross erosion. The evaluation of average annual gross erosion is equal to $15.7 \mathrm{tha}^{-1} \mathrm{y}^{-1}$ in the 1955 scenario, whereas the estimate changes to $20.5 \mathrm{tha}^{-1} \mathrm{y}^{-1}$ in the 1980 scenario. This result depends strongly on the dynamics of meadows and pastures that tend to mitigate soil erosion. These land-uses occupied $45 \%$ of Bologna's uplands in 1955 , but had almost totally disappeared 25 years later, being converted to more vulnerable land-uses like crops, arboreal cultivation and fallow land.

Due to the assumptions adopted in the analysis for the $R$ factor (i.e. stationarity of $R$ ), the application of the distributed model to these historical land-use scenarios provides estimates of the actual annual soil losses for 1955 and 1980 that may be affected by significant approximations. Nevertheless, the study results clearly show that, on average, the changes in land use dynamics between 1955 and 1980 have increased the soil vulnerability to sheet and rill erosion significantly.

\section{Acknowledgements}

The research was supported by the Ministry of University and Scientific and Technological Research (MURST) of Italy, through its $40 \%$ national grant to the programme on "Climatic and anthropogenic effects on hydrological processes", and by the National Research Council of Italy Group for the Prevention of Hydrogeological Disasters (GNDCI). The authors wish to thank the Managing Editor J.S.G. McCulloch and two anonymous reviewers for providing helpful comments and reviews.

\section{References}

Bertozzi, R., Buscaroli, A., Cavalcoli, P., Pirazzoli, M. and Vianello, G., 1992. Carta delle dinamiche di uso reale del suolo della Provincia di Bologna (Land-use dynamics map of the province of Bologna between 1955 and 1980), Parma, Italy.

Bianchi, F., Catani, F. and Moretti, S., 2001. Environmental accounting of hillslope processes in central Tuscany (Italy). In: Ecosystems and Sustainable Development III, Y. Villacampa, C.A. Brebbia and J.L. Usò, (Eds.), 229-238, WIT Press.

Brath, A. and Castellarin, A., 2001. Tecniche di affinamento delle previsioni regionali del rischio pluviometrico (Techniques for improving regional frequency analyses of rainfall extremes). In: La progettazione della difesa idraulica, U. Maione, A. Brath and P. Mignosa, (Eds.), 93-121, BIOS, Italy.

Brath, A., Castellarin, A. and Montanari, A., 2000. Detecting nonstationarity in extreme rainfall data observed in Northern Italy. In: Mediterranean Storms, P. Claps and F. Siccardi, (Eds.), 219-231, BIOS, Italy.

Calder, I.R., 1993. Hydrologic effects of land-use change. In: Handbook of Hydrology, D.R. Maidment, (Ed.), chap. 13, McGraw-Hill, New York.

ESRI (Environmental Systems Research Institute), 1994. Cell based modelling with GRID. Environmental Systems Research Institute Inc., Redlands, CA, USA.

Jain, M.K. and Kothyari, U.C., 2000. Estimation of soil erosion and sediment yield using GIS. Hydrol. Sci. J., 45, 771-786.

Julien, P.Y. and Frenette, M., 1987. Macroscale analysis of upland erosion. Hydrol. Sci. J., 32, 347-358.

Kinnel, P.I.A., 2000. AGNPS-UM: Applying the USLE-M within the agricultural non-point source pollution model. Environ. Model. Software, 15, 331-341.

Molnár, D.K. and Julien, P.Y., 1998. Estimation of upland erosion using GIS. Computer Geosci., 24, 183-192.

Montanari, A., Rosso, R. and Taqqu, M.S., 1996. Some long-run properties of rainfall records in Italy. J. Geophys. Res., D101, 29,431-29,438.

Montgomery, D.R. and Foufoula-Georgiou, E., 1993. Channel network source representation using digital elevation models, Water Resour. Res., 29, 3925-3934. 
Moore, I.D. and Wilson, J.P., 1992. Length slope factor for the Revised Universal Soil Loss Equation: simplified method of solution. J. Soil Water Cons., 47, 423-428.

Pavanelli, D., Taglioli, G. and Pagliarani, A., 2001. Rilevamento delle portate e del trasporto solido nelle stazioni sperimetali del Torrente Sillaro e del Torrente Lavino - Analisi dei dati 1997-2000 (Measures of discharge and suspended sediment load for the Sillaro and Lavino torrents - 1997-2000 data analysis). Università degli Studi di Bologna and Autorità di bacino del Reno, Bologna, Italy.

Pilotti, M. and Bacchi, B., 1997. Distributed evaluation of the contribution of soil erosion to the sediment yield from a watershed. Earth Surf. Process. Landf., 22, 1239-1251.

Pini, G.A., 1999. Tectonosomes and olistostromes in the argille scagliose, northern Apennines, Italy. Geol. Soc. America. Special Paper 335, 70 pp, 2 geological maps.

RER (Regione Emilia-Romagna) Cartographic Service, 1994. I suoli dell'Emilia-Romagna (Emilia-Romagna's soils), Bologna, Italy.
RER(Regione Emilia-Romagna)-ERSO, 1990. I suoli della collina cesenate (The soils of Cesena's district ulplands), Ellebi, Italy. Shen, H.W. and Julien, P.Y., 1993. Erosion and sediment transport In: Handbook of Hydrology, D.R. Maidment, (Ed.), chap. 12, McGraw-Hill, New York.

USDA-ARS, 1991. Predicting soil erosion by water - A guide to conservation planning with the revised USLE (RUSLE). ARS.

Wischmeier, W.H. and Smith, D.D., 1965. Predicting rainfall erosion losses from cropland east of the Rocky Mountains. Agriculture Handbook no.282, USDA, Washington, USA.

Wischmeier, W.H. and Smith, D.D., 1978. Predicting rainfall erosion losses - A guide to conservation planning. Agriculture Handbook no. 537, USDA, Washington, USA.

Wischmeier, W.H., Johnson, C.B. and Cross, B.V., 1971. A soil erodibility nomograph for farmland and construction site. $J$. Soil Water Conserv., 26, 189-193.

Young, R.A., Onstad, C.A., Bosch, D.D. and Anderson, W.P., 1987. AGNPS, Agricultural Non-Point Source Pollution Model - A watershed analysis tool. USDA Conservation Research Report, 35, 1-80. 